English Board of Trade. On my inquiring last year how the constant had been calculated I was informed by Principal Jones that it had never been calculated at all. It accordingly seemed to me that the record of any experience with current-weighers, seriously made, would be useful, and that something might be learned therefrom. The instrument in question was constructed four years ago, as a preliminary instrument. Mr. Taylor's experiments were all made before the constant was calculated. This was unfortunate, but unavoidable. When the computation was made it was found that the design of the instrument was unfortunate. Was all the work done, therefore, to be thrown away, or should it go on record for the possible information of others? What is shown by Mr. Taylor's paper is the accuracy with which it is possible to make and measure Cadmium cells, and a determination, by a method independent of the potentionmeter method, of their value in terms of Clark cells.

In conclusion, it is only fair to state that Mr. Taylor did not invent the practice of displaying more figures than are useful. In the very last edition of Everett's ' C. G. S. System of Units' still appears the quotation of Professor Miller's comparison of the pound and kilogram, in ten figures, although comparisons of three pounds at the Bureau International des Poids et Mesures differed in the fifth figure. Colonel Clark's comparison of the meter and yard is also given to nine figures. These figures have appeared for years in every British text-book of physics. We are told that death loves a shining mark. In this he apparently differs from our lively ' $\mathrm{X}$,' who, instead of turning his attention to familiar instances, seems to prefer to make merry over a man appearing for the first time before the scientific community, who will presumably not hit back.

$$
\begin{aligned}
& \text { A. G. Webster } \\
& \text { (alias ' } \mathrm{Y} \text { '). }
\end{aligned}
$$

Clark University, November 7, 1898.

\section{A TRIP TO THE TERTIARY FORMATIONS OF WYOMING AND COLORADO.}

THE Tertiary fossil beds of southwestern Wyoming have been of great interest to all paleontologists on account of the great beauty and the abundance of fossil fishes, plants and insects found in the shales of the Eocene period.

The fossils are darkened by much carbonaceous, organic matter, and are thus brought out in fine contrast and exquisite detail on the white, calcareous matrix.

The writer has always had a great desire to visit the locality, but found no opportunity of doing so until the past summer, when three weeks were spent in making excavations into the high bluffs to be seen from the station called Fossil, on the Oregon Short Line Railroad. The station is at an altitude of 8,000 feet. The fossil beds are nearly 1,000 feet higher, and above these beds are 200 feet of overlying rock. Much of this has to be removed to gain access to the fossils. The excavations are made on terraces, or shelves, along the face of the bluffs, and the work is quite laborious, and oftentimes very disagreeable from the dust constantly blown about by the wild winds of that region.

The locality is utterly barren and cheerless, the bluffs rising up from sand plains on which nothing grows but sage brush. Even in August and September it was quite cold, and icicles were hanging from the water tank at the station.

While on the bluff, three miles southwest of the station, we had our home in a stone house cut into the face of the cliff, the floor being the solid rock, on which we lay at night rolled up in our blankets. Every night the mountain rats swarmed in upon us, making it almost impossible to get any rest. All the water used had to be packed over from the east side of the mountain from the only spring of drinkable water in that vicinity; even this was quite alkaline. All these discomforts were cheerfully endured and compensated for, in making one of the finest collections ever obtained from that locality.

Beautiful palms and other plants, and hundreds of fishes and insects were obtained. From Fossil a trip was made into Utah, where some fine minerals were secured. After a week of rest at Salt Lake City the road homeward was taken, by way of the Colorado Midland, stopping over two weeks at Florissant, Colo., where over 700 beautiful specimens of fossil plants and insects were obtained from the 
world-renowned Miocene beds of that locality. In the immediate vicinity are to be seen the petrified remains of an ancient forest. One of the stumps measured fifteen feet in diameter. The whole surrounding country shows the effects of igneous action in past ages. This is especially noticeable in the rear of the postoffice in Florissant, where the granites are rent into fearful chasms, and where several deep, extinct geyser funnels may be seen, worn on the interior perfectly round and smooth by the action of water.

A trip was taken to Crystal Peak, four miles north of Florissant, where some fine Amazon stone was obtained. This completed the work of collecting, which, in every respect, has given very gratifying results.

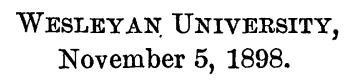
LITERATURE. .

IN SCIENCE for October 28th there is a notice of the Second Conference on an International Catalogue of Scientific Literature, and it is said that a decimal system has been recommended.

At this critical time (before the work has been begun) there ought to be open discussion by cataloguers, and the most liberal attention given to the wishes of the users of such a catalogue. A repetition of the English catalogue, monumental but not used, is to be avoided. The most important characteristic of a catalogue of scientific literature ought to be its convenience to the user; this quality ought to prevail over all other qualities of such a catalogue. The possible wants of a user of the catalogue should be constantly thought of and provided for by the cataloguer.

The user is interested in his subject, probably not in cataloguing. He wants to find quickly and easily what has been published on a certain branch of Science. He does not want to learn a system of classification nor its method of application, as he would have to do in the case of the decimal system. He wants to find his subject in the alphabetical order, as he would in an encyclopædia ; first the title, then the date, then the author and the size of the work.
The list of subjects should be derived from the titles as they are being collected, and it should be arranged in alphabetical order, for the convenience of the user.

In doubtful cases and where more than one branch of a subject is treated in a paper a title should be repeated under as many subjects as by the most liberal construction a user is likely to look for it, with too many repetitions rather than too few.

Ask the users if I am not right; and for whom else is the catalogue to be prepared?

In a case like that of the great English Catalogue of Scientific Papers, where the titles are arranged in the order of the authors' names with a number against every title, the numbers only need be collected and classified; or the numbers and the dates (though this would perhaps double the cost of publication). And here again the user should be considered by making the list of subjects large and by putting them in alphabetical order.

Alfred Tuckerman.

New YoRK, November 5, 1898.

\section{SCIENTIFIC LITERATURE.}

Charles Darwin and the Theory of Natural Selection. By Edward B. Poulton. New York, The Macmillan Co. 1896.

This was not only a very timely book when it appeared, but will always be one of the minor classics of evolutional literature. It is well and clearly written, compact, and a most handy book of reference for the student of Darwin's life and work, by a sincere and orthodox Darwinian. Not only does Professor Poulton give us the leading facts in Darwin's life, but in a happy and skillful way he tells the secret of his greatness, when and how the fact of evolution was impressed upon him, and the date when the idea of natural selection as an efficient cause was suggested to him. The two discoveries of Darwin which led him to reflect on the principle of evolution were, first, the fossil armadillos of the Pampean deposits and their relation to those now living, which led him to remark, in 1837, in his 'Naturalist's Voyage round the World:' "This wonderful relationship in the same continent between the 